\title{
THE PHONOSEMANTIC RESEARCH OF AZERBAIJANI AND TURKISH IN THE ASPECT OF LITERARY LANGUAGE AND DIALECT
}

\author{
PhD. Teymurlu Z. M. \\ Department of the Azerbaijani Language and Literature \\ Baku Engineering University, Azerbaijan, Baku
}

DOI: https://doi.org/10.31435/rsglobal_wos/28022020/6915

\begin{abstract}
ARTICLE INFO
Received: 14 December 2019

Accepted: 19 February 2020

Published: 28 February 2020

\section{KEYWORDS}

the Azerbaijani language, the Turkish language,

literary language,

dialect,

phonosemantics
\end{abstract}

\begin{abstract}
Discovering and categorizing phonetic, morphological and lexical units related to different languages in any language, studying the factors and forms of language connections are still among trending issues nowadays. Special importance has been attached on dialect lexicon of languages, historical-comparative study of literary language and finding out various language elements in the paper. Some researchers support that as Turkic peoples have been formed as independent or semi-independent nations completing ethnosocial differentiation process since the late Middle Ages, their languages differ from one another to some extent. The emergence of different Turkic states has led to the appearance of common and various features in the peoples and their languages who experienced public-political differentiation. In this case if the existing analogical features are proof for the closeness of these languages, distinct features are indeed the confirmation of peculiar development direction of each language. The research work provides some vision about common and distinctive features of the Azerbaijani language dialects and the Turkish language. The characteristics of languages' mutual influence are reflected in language material.
\end{abstract}

Citation: Teymurlu Z. M. (2020) The Phonosemantic Research of Azerbaijani and Turkish in the Aspect of Literary Language and Dialect. International Academy Journal Web of Scholar. 2(44). doi: 10.31435/rsglobal_wos/28022020/6915

Copyright: (C) 2020 Teymurlu Z. M. This is an open-access article distributed under the terms of the Creative Commons Attribution License (CC BY). The use, distribution or reproduction in other forums is permitted, provided the original author(s) or licensor are credited and that the original publication in this journal is cited, in accordance with accepted academic practice. No use, distribution or reproduction is permitted which does not comply with these terms.

Introduction. "The formation of Azerbaijani and Turkish that are from South-Western Oghuz sub-branch of Turkic languages dates back to ancient times". The Turkic languages as well as the Azerbaijani language are included in agglutinative languages according to their morphological classification. Since their genetic, typological, grammatical structures and basic vocabulary fund are common, they unite in a single family. This family is called "the Turkic languages". Among the Turkic languages Azerbaijani and Turkish are closer to each other for their phonetic, lexical and grammatical peculiarities.

The analysis of Azerbaijani and Turkish in terms of sound, word and form as well as observation of differences in terms of phonetics, morphology and lexicon alongside with common words existing in these languages are corresponding to originally historical progress of Oghuz languages.

The main reason behind the emergence of dialect differences in a language is relative isolation of various alignments of language unity and decrease of linkage. For this reason, physical-geographical factors (mountaion ridges, water resources, forrest massifs, deserts etc.) dominate among the factors that complicate communication. Generally, territory factor is key in the diversity of dialects. Though these languages are used in separate states in terms of executive territory, they have been able to preserve common language peculiarities. When we look through Azerbaijani and Turkish in the aspect of literary language and dialect, it becomes clear that these languages have been able to save common language 
features in the background of literary language or in dialectal background. Today we come across language features that are inherent to the Turkish literary language in the dialects of Azerbaijani. Common language characteristics are observed in both the Turkic languages' dialects. Discovering common language features in the direction of literary language and dialect is the case in point for preserving ancient historical linguistic features of Turkic languages. As a result of the comparison between two regions based on the dialect facts new ancient language facts have been found out.

The research conducted in the aspect of literary language and dialects is of great importance in the detection of the impact of interdialect processes that carry on in both the languages, and literary languages on dialect. Direction fields of the research are the following:

\section{Dialect and the research conducted in the background of dialect}

The dialects in the Azerbaijani language are compared with the Eastern dialects in Anatolia here. Similar phonetic, morphological features have been discovered in both the dialects during the research. This adequacy brings Anatolia's Eastern dialects closer to Azerbaijani dialects. The research has been carried out based on phonetic and morphological peculiarities discovered by L. Karahan in Anatolia's "East group dialect" classification and that are separated from Anatolia's North-East and West group of dialects. Considering the dialectological features crucial listed by the author, other dialectological research papers have also been reviewed in the research in the background of literary language and dialect. During the research it became certain that dialects in the regions Kars and Erzurum reflect the features of Azerbajani dialects more. And the reason behind it is the historical settlement of Azerbaijanis in these regions. "Today original settlement area of Kars Azeris is Surmali area that embraces Tuzluca, Igdir and Mediterranean districts. Most of the people living in these districts and villages are Azeri. The region where they are dense and crowded outside Surmali area is Arpacay district. Most villages of this district, especially Bashgedikler consist of Azeris. Furthermore, a good number of Azeris dwell in the center of Kars and in some villages that depend on the center" (Ercilasun, 1983:47). E. Gemalmaz noted that the dialects in the region Erzurum bear traces of Turkmen-Azeri-Terekeme dialects (Gemalmaz, 1995:22).

\section{Dialect and the research conducted in the background of literary language}

Phonetic, morphological and lexical features of Azerbaijani dialects have been comparatively studied with the Turkish literary language here.

Although the modern Turkic languages were formed from common Turkic roots, gradually there emerged some different characteristics in their phonetic, lexical and grammatical structures. Figuring out common and different features in related languages during the research of the separate Turkic languages enables us to comprehensively learn the specific features of the studied language.

\section{East group dialects of Azerbaijan and Anatolia:}

Anatolia's East group dialects comply with Azerbaijani dialects and dialects of Iraq Turkmens' South and South-East group dialects in terms of language features. According to the classification by M. Shiraliyev, dialects of Kars Azeris that live in the East in Surmali area that covers the regions Tuzluca, Igdir, Mediterranean, in Arpacay and partially in the center of Kars comply with South group dialects (Nakhchivan, Ordubad, Erevan) of Azerbaijani (Karahan, 2011:54). Iraq-Turkmen dialect also complies with South group dialects of Azerbaijani (Iraq-Turkmen dialect 2004: 44).

M. Shiraliyev considers dialects of Kars Terekemes living in Cildir, Arpacay, Susuz, Selim and in the center of Kars close to the West group (Gazakh, Ayrum-Borchaly) of that classification (Karahan, 2011:54). Terekemes that came to Kars are "Cildir terekemes" who are mostly called "Karakalpak" today. They used to live in the regions Borchaly and Gazakh that depended on Gazakh-Shamsaddin khanate in North Azerbaijan, at the time Turkmenchay contract was signed in 1828 they abandoned their birthplaces and came to Kars and settled down in the villages of Cildir and Ardahan. Some of them moved to Iran, most of them are living in the regions Gazakh, Tovuz and Aghstafa in Gazakh (Ercilasun, 1983:44). Azerbaijanis migrated from their ancient Oghuz land in various years. And also after Kars contract was signed (in 1921, October 13) Karapapaks who didn't want to stay in the territory of newly established Armenia and in the subordination of Armenians and who lived in the villages Mumukhan, Siniq, Tezbahar, Arpa, Boyuk Shishtapa, Kichik Shishtapa, Sultanabad, Soyudlu, Mustuqlu, Bahceli, Seldaghilan, Kichik Tapakoy, Khancalli, Bozgala, Ordaklu, Gonchali, Tezekoy as well as Akbaba migrated to Turkey protesting the bordering and never came back. Currently in Kars, Erzurum, Cildir, Ardahan, Sarykamysh, Igdir and some other places thousands of Akbaba people are living (Bayramov, Bayramova, 2014:17-19). A. B. Ercilasun calls dialects of Kars region "the circle connecting Azerbaijan with Turkey" in terms of ethnic and dialectic factors. He notes that one end of this circle extends to 
Erzurum, Coruh and Central Anatolia, and the other end extends to Baku, Nakhchivan, Erevan, Akhbaba, Akhalkalaki, Tbilisi, Gazakh, Borchaly and Akiska (Ercilasun, 1983:145).

M. Ergin highlights: "Oral language of East Anatolia is Azeri, written language is natural Turkish. The features and influence of Azerbaijani are felt beginning from Kars to Samsun-Sivas-Iskenderun line and sometimes to the inner parts of Central Anatolia. However, this influence weakens gradually from East to West. Kars province is where the usage of Azerbaijani dominates in Anatolia" (Ergin, 1971:9).

Today the reason behind the closeness between East Anatolia dialects and the Azerbaijani language is the Azerbaijanis who once migrated here: "Most of them spread into some villages as well as small towns. Therefore, Kars province has rich folklore of dialects which is unimaginably diverse" (Jafaroglu, 1995:12;296). The dialects of Terekemes living in the areas Cildir, Susuz, Selim areas in Kars and in the villages dependent on the center of Kars; the dialects of Azerbaijanis living in the villages Tuzluca, Igdir, Mediterranean located in Surmali and in the villages dependent on Arpacay and Kars center differ from the dialect features of East group of Anatolia (Karahan, 2011:55). L.Karahan divides East dialects of Anatolia that are different in terms of phonetics and grammar into groups and calls these groups "sub-branches". The author's classification is like this: Group I: Agri, Van, Mush, Bitlis, Bingol, Siirt, Diyarbakir, Mardin, Hakkari, Urfa (except Birecik, Halfeti), Palu, Karakochan (Elazig) dialects; Group II: Kars (except Ardahan, Posof), central Erzurum, Ashkale, Ovacik, Narman, Pasinler, Horasan, Hinis, Tekman, Karayazi, central Erzincan, Tercan, Chayirli, Kemah, Refahiye, Gumushane dialects; Group III: Ardahan, Posof (Kars), central Artvin, Shavshat, Yusufeli, Ardanuch (Artvin), Oltu, Tortum, Olur, Shenkaya, Ispir (Erzurum) dialects; Group IV: Kemaliye, Ilich (Erzincan), central Elazig, Keban, Baskil, Aghin, Harput (Elazig), Tunceli dialects (Karahan, 2011:58).

As it is obvious, the role of the public-political processes that the history established is undeniable in the emergence of dialects. "The emergence of dialects is not an issue of today, dialect is a historical category" (Azizov, 2016:291).

The researches conducted show that the same language fact can be related to both literary language and dialect. During the comparison of language facts hopeless situation appears in several cases, the samples involved in the study bring about questions. Thus, it becomes possible to determine which of the words belong to literary language or dialect as a result of historical-comparative research. During the comparison of East-Anatolia dialects with Azerbaijani dialects in terms of language features relevant language features have been taken into account in the mentioned sub-branches. This coherence indicates itself in phonetic changes, usage of suffixes and in lexical direction. Some phonetic, grammatical and lexical features that belong to ancient layers of a language leave literary language in certain periods and are antiquated, but these forms are maintained in everyday folk dialects.

\section{Changes in East Anatolia dialects in terms of phonetics}

1. Replacing vowels "l,u, ü" with vowel " $i$ " (gözi) (Karahan, 2011:56). We encounter the violation of vowel harmony in Azerbaijani dialects: yüzi (Ordubad, Kotam), üzdi, düşir, düzdi, kusib, sürdik (Baku, Shamakhi, Mughan), üzimizi, yüngüldi, küni (Nakhchivan-Nehram), uni (Ordubad) etc. (Karahan, 2011:59). A misfit that is wide-spread in words that have thick vowels emerged in East and North-East Anatolia dialects with 1's becoming thin vowel: ganli (Amasya), olma $m i$ (Amasya), ayrilan (Amasya), etrafi (Kars), taflanif ki (Kars), tudti (Kars), garısi (Kars), çadiri (Kars), alirmiş (Kars), ahilli başli (Erzurum) (Korkmaz, 1994:38).

2. The consonant $H$ is specific to this dialect group. (aldıh) (Karahan, 2011:56). "Durnam geder olsan bizim ellerel/ Gatıh söyle, gaymah söyle, yağ söyle" (Gudretullah Iydirli// Igdir: from Yukari Çarıhçı 'Carikci' village) (Jafaroglu, 1995:94;296). The same case appears in Azerbaijani dialects as well: aldıx, aldux (Shaki), qurdux (Shaki, Zaqatala, Qakh), işdədlx (Nakhchivan-Nehram, Ordubad, Tabriz, Shaki, Zaqatala, Qakh) (Shiraliyev, 2008: 203).

3. Consonant " $\tilde{n}$ " disappeared having changed or fallen (aldın, baa) (Karahan, 2011:56). We don't observe the sound " $\tilde{n}$ " in East dialects of Azerbaijani. But in West group of dialects this sound is widely used. The sound "ñ" gave its nasal feature to the vowel before or after it disappearing gradually in dialects of Shaki, Zaqatala-Qakh, Nakhchivan and Ordubad. (doār, maā, oliı̌, aldıı̌z) (Shiraliyev, 2008:73). When personal pronouns are used in dative case in dialects of Kars Azerbaijanis and Terekemes, the consonant " $\tilde{\mathrm{n}}$ " is fallen and two vowels are created: maa, baa (Jafaroglu, 1995:138;296).

4. Hard palate consonant " $g$ " is kept between two vowels and at the end of syllable (döger) (Karahan, 2011:56). In Azerbaijani dialects this case is observed between two vowels or between two vowels and sonorant sounds in East dialects: ignə, dügi, dügmə, dügün etc. (Shiraliyev, 2008:86).

5. In some certain words initial phoneme consonant " $y$ "has fallen (igit) (Karahan, 2011:56). In some words in the Turkish literary language " $y$ " which is counted one of ancient phonemes has 
been kept in the beginning of the words, while in Azerbaijani these have undergone to sound falling: ylldırım "ildırım", ylldız "ulduz", yllkl "ilxı", yllan "ilan", yiğit "igid". Falling of the consonant " $\mathrm{y}$ " is mainly found in the dialects of Azerbaijanis in Kars region: üz, ilan, uca, il, üzüh, ürəyim, itdi, igirmi etc. (Jafaroglu, 1995:135;296). This case is peculiar to the Azerbaijani literary language. Azerbaijani. üz - Turkish. yüz, Az. İlan - T. yllan, Az. uca - T. yüce, Az. il - T. yll, Az. üzük - T. yüzük, Az. ürayim - T. yüreğim, Az. itdi - T. yitdi, Az. iyirmi - T. yirmi.

6. Phonetics plosive consonants especially in number names double (yeddi) (Karahan, 2011:56). This case is peculiar to the Azerbaijani literary language: yeddi, sakkiz, doqquz. In the dialects of Erzurum region "-nn-, -11-, -ss-, -cc-, -mm-, -gg-, -zz-, -bb-" consonant doubles are mainly found: [annım] «anlım», [yallat] «aldat-», [yassi] «yatsı», [ducci] «tuzcu», [memmet] «mehmet», [möggem] «muhkem», [ezza] «ecza», [mebbuz] «makbuz» (Gemalmaz, 1995:216).

7. Sound changes between " $g-r, p-r$ " consonants are widespread in these dialects (dorğu,torpah). (Karahan, 2011:57). This case is often observed in dialects of Erzurum region. : [torpa $\approx]$ «toprak», [yarpa $\approx]$ «yaprak», [örgen-], «ögren-», [çilpa $\approx$, «çıplak», [kölmex]/[çölmex] «gömlek», [terkaldan] «tekrar[dan]», [gürbe] «gübre», [arği] «ağrı» etc. (Gemalmaz, 1995:206-207). The change of sounds inside a word is inherent to the Azerbaijani spoken language: yanlış-[yalnış $(n l-$ In)]; maşhur-[mahşur(şh-hş]. (Gurbanov, 2003:95). This case is also found in Azerbaijani dialects (Jalilabad, Salyan, Gadabay, Nakhchivan, Sharur, Ordubad, Goychay, Lankaran, Masally): çölməg//çölməx Y/çölməy çömlek (Azerbaijani Language Dialectological Dictionary, 2007:106).

8. The 2 nd person plural personal suffix and possessive suffix are "-z". (geldiz, babaz) (Karahan, 2011:57). As it seems " $y$ " sound has fallen here as well. In Azerbaijani dialects it is possible to see both " $n$ " form and shortened forms of suffix of possessive in the second person plural. For example: komuz, baltaz, keçız (Shaki), ata:z, baba:z, qutu:z (Zangilan), ăgacı:z, dardi:z, yolu:z, gözü:z (Khojavend) (Mammadli, 2019:140). Alongside with this, replacement of " $y$ " consonant with " $\mathrm{n}, \mathrm{g}, \breve{\mathrm{g}}, \mathrm{y}$ " consonants is also possible. In the dialects of Kars Azeris " $\mathrm{n}$ " sound is essentially preserved. But change in the direction of $\eta>y$ in the dialects of Tuzluca Azeris, especially in Pulur village unite Azeris of this region with Nakhchivan region: eliyiz, qoluyuz (Ercilasun, 1983:120). Just as in dialects of East Anatolia, the 2nd person plural possessive suffix in past categories tense in Azerbaijani dialects is “-z": galdiz (Sharur), tuttu:z (Zangilan), içti:z (Tabriz) (Mammadli, 2019:224).

9. $b>m$ change. This change is observed in East Anatolia dialects. "Mirze Mehmet çı̧i, dęyi: menim babami gözümün garşında yime, men sag̉am. Evvela meni yi, sorā babami yi." (Van) (Jafaroglu, 1995:3;288), "Gülli hamamin üsdiyem/İncitme meni hesdeyem /Bağla yarami yarami”" (Mush) (Jafaroglu, 1995:82;288), "Mineydim gemisine, Ömrümün hemmisine" (Ahlat), "Nali parlatdi getdi, meni aġlatdi getdi" (Ahlat) (Jafaroglu, 1995:53;288). The 1st person personal pronoun is "mən" in the Azerbaijani literary language. During the period when "Book of Dede Korkut" ephos was formed, domination of mən form in Azerbaijani should be understood as a language feature of ancient local tribes, and ban should be considered a language feature of Oghuz-Seljuk tribes who came afterwards. (Azizov, 2016:104). B>m change is found in most dialects of Azerbaijani in demonstrative pronouns. In demonstrative pronoun "bu" sound " $b$ " is replaced with sound " $\mathrm{m}$ " in all cases except nominative case. For example: "bunun>munun//minın, muna//mına, munu//munı, munda//minda, mundan//mından" (Shiraliyev, 2008:76). This case is inherent to the Turkmen literary language. The demonstrative pronoun "buu" undergoes some changes in other cases unlike nominative case in the Turkmen literary language. For instance: "munuñ, munı, muña, munda, mundan, munça" (Kara, 2005:111). B $>$ m replacement is encountered in dialects of the Turkmen language. We can observe the following changes: "boyun>moyın" in Yomut - Gunbatar dialect, "büdüremek>müdüremek" in Arsari and Stavropol Turkmens' dialects, "bol>mol" in Karakalpak Turkmens' dialects, "buzav>mizov" in Kirac dialects. (Berdiev, Kurenov, Shamuradov, Arazkuliyev, 1970:116). B>m case covers other words in Azerbaijani dialects as well: məyiz, moyun (Gadabay), mayla-, məzkək, müdrimək (Imishli), miz>biz (Nakhchivan-Koshadiza, Sharur-Yengica), mayladl, xoruz mayı (Gazakh), munca (Shaki-Orta Zayzid) (Azizov, 2016:104).

\section{Changes in East Anatolia dialects in terms of morphology}

10. Vowel of present tense suffix is narrow (geliy, gelêr, gelī) (Karahan, 2011:57). In some dialects of Azerbaijani such as Shaki-Zaqatala-Qakh, Ordubad and some dialects of South Azerbaijan present tense is expressed with the suffix "-iy". In Gazakh dialect of Azerbaijani "-êr//-er" suffix of present tense is found (Shiraliyev, 2008:215). "-1,-i,-u,-ü" suffixes of present tense are observed in some village dialects of Azerbaijan such as Baku, Shamakhi, Khanlar, Goychay, Jabrayil, Tovuz, Lankaran (alu, gəlü, duru, kətiri, ol1, bili) (Shiraliyev, 2008:216). "-ir" from present tense suffixes "-1r,-ir,-ur,-ür" that belong to the 
Azerbaijani literary language is used in the dialects of Ahlat, Agri, Malazgirt and partially central Bingol: gelir, kzzir, ohirlar, oynirlardi, bahir, bahirik, edirem (Karahan, 2011:75).

11.The 1st person singular and plural negative simple present tense suffixes in East group dialects such as in Van, Ahlat, Diyarbakir and Urfa are like "-manam/-menem, -manih/menth/-menik": unutmanam (Van), satmanam, satmanıh (Urfa), içmenem, içmenıh (Diyarbakir) (Karahan, 2011:74). Unlike the Azerbaijani literary language "-manam,-mənəm,-manı $\breve{g}$,-mənig" suffixes are observed in several dialects. (Shiraliyev, 2008:235): başdamanam/başdamaram, galmanix //galmarix', galmənix (Nakhchivan, Erevan city, Ordubad, Tabriz, Zaqatala, Qakh) (Shiraliyev, 2008:237-238). Unlike the Azerbaijani literary language, the 2nd person and sometimes the 3rd person singular negatives are like "mar, mər" in dialects. Though these suffixes have been preserved only in the first person in literary language and "-maz, -məz" suffixes are used in the second and third persons: başdamaram, başdamarıx (Karabakh, Aghdam, Ganja, Gazakh) (Shiraliyev, 2008:236-237). In dialects of central Mush, Bulanik and Malazgirt in Turkish this suffix "-r" emerged from the combination of present simple tense suffix as well: almaram, almarsan, almaroh, almarsiz (Karahan, 2011:74).

Usage form in the Azerbaijan literary language: söylə-mə-r-əm, söylə-mə-z-sən, söylə-mə-z; söyla-ma-r-ik, söyla-ma-z-siniz, söyla-ma-z-lar.

12.Studied past tense suffix is "-mış, -miş" in most dialects of East group. "-1p/-ip" that is past tense suffix and is currently used in Azerbaijani and Iraq Turkmen dialects are used in Bulanik, Ahlat, Adilcevaz and Van dialects. Ahlat is the border of this suffix. Past tense suffix used in Mush and Bitlis is "-miş". (Karahan, 2011:73).

Usage form of past tense learnt in Azerbaijani: al-mış-am, al-mış-san (alıbsan), al-mış-dır (alıb; alıbdır); al-mış-ıq, al-mış-sınız (alıbsınız), al-mış-lar (alıblar).

The research conducted in the background of dialect and literary language:

We can characterize phonetic and morphological features of Azerbaijani dialects and the Turkish literary language like below:

1. While in the Azerbaijani literary language, "i" sound is observed in the beginning of a word disrupting vowel harmony, " 1 " sound is encountered in Gazakh, Ganja dialects and in some dialects of Karabakh. For example, ışıx, ılxı, ıldırım etc. (Shiraliyev, 2008:56). Unlike Azerbaijani, usage of $\iota$ vowel in the beginning of a word is typical in Turkish: ışı «işıq», ırak «iraq», lsı «istilik».

2. Addition of "y" sound in Azerbaijani dialects (especially in Zaqatala-Qakh dialect) reflects itself on a large scale. We come across with the traces of "y" sound addition in dialects of Nakhchivan and West. " $y$ " sound is not strong in the beginning of a word in Gazakh dialect. However " $y$ " sound addition is observed in some village dialects which Gazakh dialect covers: yuldurum// yıldırım, yllxl (Zaqatala, Qakh) (Shiraliyev, 2008:94). "y" which is counted as ancient phoneme was preserved in the beginning of some words in Turkish. But in the Azerbaijani literary language these underwent sound falling: yıldırım «ildırım», yıldız «ulduz», yılkı «ilxı».

3. Words that end with vowels in accusative case of nouns are formed with "-y1" suffix in Azerbaijani dialects such as Ayrum, Shamkir, Tovuz, Qazakh and Borchaly, as well as in the village dialects of some isled regions (Sharur, Sadarak, Kalbajar, Jabrayil, Zangilan, Baku, Salyan): qapıyı, doriyi, quzuyu, sürüyü (Gazakh), almeyl//almayı, qonşuyu, kişiyi (Ayrum) (Azizov, 2016:268). This case happens in the Turkish literary language as well: elmayl, kapıyl, deriyi, kuzuyu, sürüyü, komşuyu, kişiyi etc.

4. Thick consonant " $\mathrm{"}[\mathrm{k}$ '] is encountered in the beginning of some words in West dialects: 5ış, 5uş, 5utu (Gazakh, Borchaly), 5ifil (Tovuz, Borchaly), suş, sılfıl, 5ısıı (Sharur) (Azizov, 2016:267). This case happens in the Turkish literary language as well: kış, kuş, kutu, kısır etc.

5. The negative form of the verb's potential form is made with "-amma, -əmmə" suffixes in West group dialects of Azerbaijani: yazammadl, görammədi, qaçammaz, üzəmməz etc. (Shiraliyev, 2008:21). In Turkish the verb's potential form is expressed with "-ama, -eme" suffix: yazamadl, göremedi, kaçamadl, yüzemedi etc.

6. Pronoun "kendi" replaces pronoun "öz" in Azerbaijani dialects: "gəndi" (Gazakh, Shaki) “öz”- Biz gəndi adətdərimizi yaxşı bilerix' (Gazakh) (Azerbaijani Language Dialectological Dictionary, 2007:178). This case happens in the Turkish literary language as well: kendi dilim "öz dilim", kendi odam "öz otağım”, kendi kendine “öz-özünə”.

7. Vowels are used in "-yor,-yör" form according to harmony in verbs that end with vowels "u, ü" in West dialects of Azerbaijani: oxuyor, toxuyor, sürüyör (Gazakh) (Azizov, 2016:266-268). Present tense form is made adding a single form "-yor" suffix to the root of the verbs in the Turkish literary language as well: geliyorum «gəlirəm», okuyorum «oxuyuram», söylüyorum «söyləyirəm». 
8. While " $a v$ " sound combination is kept in Turkish, it changes its place in Azerbaijani. In Turkish: av, avuç, tavşan, tavuk; in Azerbaijani: ov, ovuc, dovşan, toyuq. But "av" sound combination is kept in dialects of Nakhchivan, Shahbuz, Sharur, Zangilan, Gubadly, Jabrayil, Fuzuli (Gharabulagh): davşan, yavşan, qavla - (Azizov, 2016:267).

Semantic similarity of Azerbaijani and Turkish

A sign that is dialect feature in Azerbaijani is considered a literary language feature in Turkish. In some cases we observe the opposite.

For instance, the word "sülüx"» which we observe in Bashkechid, Borchaly dialects of Azerbaijani is encountered in the Turkish literary language. (Azerbaijani Language Dialectological Dictionary 2007:450): Şimdi gidip yanağıma beş on sülük yapıştıracağım (Faik Reshat) (Ayverdi, 2006:2873). The meaning of this («zoli») word is the same in both the Turkic languages: leech.

The words «Dalda// Dalday// Daldey» mean "a place where doesn't see wind, rain or Sun" in the dialects of the Azerbaijani language (Baku, Karabakh, Fuzuli, Goychay, Kurdamir, Qakh, Mingachevir and others): Heyvannarl çek, daldada saxlaginən (Baku); Yeydə daldada uturanda isdi güc eləmiy (Qakh); Daldada düzəliv işdi:rik (Fuzuli); Malçının bağı daldaydadı, onö:rə da meyvənikülax' töx'mür (Chenberek); A Ăacın altında daldey vardı (Gazakh); Ojağı daldeyda qala (Ganja); Bu yağış bizim əhdimizi kəsəjəx'; o qa:lığda daldey olar (Shamkir) (Azerbaijani Language Dialectological Dictionary 2007:112113). This word is faced in dulda form in the meaning «a part of a place where doesn't see Sun, wind or other things, a shield» in the Turkish literary language. «A silent, out of sight, alone place» meanings are also typical in the Turkish literary language: (...) hayli aralıklı dut ağaçlarının ve kavakların duldasina yapılmuştı (Mustafa N. Sepetcioglu) (Ayverdi, 2006:764). In ancient Turkic monuments dalda $>$ dulda form was used (Blagova, 1982:60). The word "dulda" was used in «patronage» meaning in Karacaoghlan's works: Yiğit duldasında yiğit saklanır/Muhannette gölge olmaz dal olmaz (Ayverdi, 2006:764). The mentioned meaning is faced in Amasya, Kayseri, Nigde, Adana dialects of Turkish (Compilation Dictionary. Vol: 4. http://tdkterim.gov.tr/ Dictionary of Turkish Dialects). Two meanings of the word dalda is faced in Karakoyunlu village of Igdir in Turkish:

Ezizim dalda «arxada» yeri

Elemi daldadı dalda yeri

Muhannet gözderim gene ahtarır

Tez tapar gene dalda «gizli» yeri (Jafaroglu, 1995:9;296).

The word Dalda is used in the meaning «a place where is protected from wind, Sun or rain» in most dialects of Turkish (Compilation Dictionary. Vol: 4. http://tdkterim.gov.tr/ Dictionary of Turkish Dialects). Actually the word dal could be characterized in the meaning «back». But linguists related the lexical unit dalda to Mongolian-Tungusic languages. In Mongolian dalda means "bulwark", dalimeans "to close, to hide", daliqa means "closed place, wall". In ancient Turkic the meanings "to close, to hide" were expressed with the word yaşur-. Yaşmaq means "veil" in Turkish. Based on these samples, E. V. Sevortyan relates the word dalda dalda- to common Altay lexicon and has a critical approach towards its being Turkish originally (Sevortyan, 1980:138-139).

The word «alliq//allix» is faced in the meanings "cloth to take hot dish from the fire" (Imishli); "armband or sleevelet to take hot bread out from tandoor" (Salyan); "mitten" (Barda, Borchaly, Gazakh, Gadabay, Lachin) in Azerbaijani dialects: Ollig çörək yapanda lazım olur (Salyan); Olligi mə:, qazanı götürüm (Imishli); Olliyin dörd barmă̆ı bir olur, baş barmă̆ ayrı olur (Barda); Ollix yunnan toxunar (Borchaly); Ollix `siz qlşda əzməy < gazmək> olarmı, ə:arvad? (Gadabay) (Azerbaijani Language Dialectological Dictionary 2007:159). The word allik isn't faced in the Turkish literary language. This word means "gloves, thick protective gloves" in Turkish dialects (Compilation Dictionary. Vol: 5. http://tdkterim.gov.tr/ Dictionary of Turkish Dialects): Eller, göbeк üstünde, уок bir şey umrunda / Ellikten çıkmış eller, ектек uğrunda (Ziya Osman Saba «Hands»).

The words bildir «last year», sancaq «different-sized and formed woman accessory made of plain or valuable metal to pin to breast or hair» that are used in the Azerbaijani literary language aren't used in the Turkish literary language. But these are encountered in Turkish dialects: the word bildir means «last year» in Afyon, Bolu, Kars, Adana dialects (Compilation Dictionary. Vol: 2. http://tdkterim.gov.tr/ Dictionary of Turkish Dialects); the word sancaq means «different-sized and formed woman accessory made of plain or valuable metal to pin to hair» in Kars dialect: İkiüç sancah al, başıma sancajam (Compilation Dictionary. Vol: 10. http://tdkterim.gov.tr/ Dictionary of Turkish Dialects).

Conclusions. Comparative research of Azerbaijani and Turkish in the background of dialects and literary language enables us to determine similar or different phonosemantic features between these 
languages. We can conclude that the determined phonetic, morphological and lexical similarity in language materials are closely due to the reasons that those languages have been fed from the same root and existed in historically close periods. It's undeniable that both the languages have common language characteristics. One of the main reasons behind this is the migration of Azerbaijanis from their ancient lands. The most undeniable historical fact is the ethnic familiarity of the people speaking in these languages.

During the research of Turkic languages revealing common and different features in related languages provides a good opportunity to learn the specific features of the studied language in detail. Some phonetic, grammatical and lexical features that belong to ancient layers of a language leave literary language in certain periods and are antiquated, but these forms are maintained in everyday folk dialects. Two related languages that share the same geography historically embarking on a path of development on their own led to the emergence of tangible differences between these languages. As a conclusion we can say that though Azerbaijani and Turkish are close due to phonetic, lexical and grammatical features among Turkic languages, there exist different phonetic, morphological and lexical peculiarities alongside with respective language elements. A sign that is a dialect feature in Azerbaijani is considered a literary language feature in Turkish and vice versa. In our opinion, approaching the semantics of words in general context is more advisable. It's very difficult to determine the exact history of mutual influence opportunities of Turkic languages based on dialect carriers. Thus, comparison of two related languages based on language materials indicates the closeness of these languages on dialectal level.

\section{REFERENCES}

1. Ayverdi I. Large Exemplary Turkish Dictionary, $1(A-G)$, Istanbul: Kubbelalt1, 2006. - 1125 p.

2. Ayverdi I. Large Exemplary Turkish Dictionary, 2 (H-N), Istanbul: Kubbealt1, 2006. - 2372 p.

3. Ayverdi I. Large Exemplary Turkish Dictionary, 3 (O-Z), Istanbul, Kubbealt1, 2006. - 3549 p.

4. Azerbaijani Language Dialectological Dictionary, Baku, 2007. - 566 p.

5. Azizov E., Azerbaijani Historical Dialectology (Evolution and İmprovement of Dialectal System). Enriched second edition. Baku, 2016. - 347 p.

6. Bayramov A., Bayramova A. "Akbaba Dialect Dictionary". Baku, 2014. -280 p.

7. Berdiev R., S. Kurenov, K. Shamuradov, S. Arazkuliyev. Essay on the Dialects of the Turkmen Language. Ashgabat, 1970.

8. Blagova G. F. Usage of Turkic Phrases in Historical Dialects Belonging to Certain Areas. Moscow, 1982. 304 p.

9. Compilation Dictionary. Vol: 2. http://tdkterim.gov.tr/ Dictionary of Turkish dialects

10. Compilation Dictionary. Vol: 4. http://tdkterim.gov.tr/ Dictionary of Turkish dialects

11. Compilation Dictionary. Vol: 5. http://tdkterim.gov.tr/ Dictionary of Turkish dialects

12. Compilation Dictionary. Vol: 6. http://tdkterim.gov.tr/ Dictionary of Turkish dialects

13. Compilation Dictionary. Vol: 8. http://tdkterim.gov.tr/ Dictionary of Turkish dialects

14. Compilation Dictionary. Vol:10. http://tdkterim.gov.tr/ Dictionary of Turkish dialects

15. Ercilasun A. B., Kars Region Dialects (phonetics). Ankara, 1983. -386p.

16. Ergin M. The Azerbaijani Language. The 2nd edition, Istanbul, 1971. $-256 \mathrm{p}$.

17. Explanatory Dictionary of the Azerbaijani Language: in 4 volumes, vol I, Baku, 2006. -740 p.

18. Explanatory Dictionary of the Azerbaijani Language: in 4 volumes, vol II, Baku, 2006. -790 p.

19. Explanatory Dictionary of the Azerbaijani Language: in 4 volumes, vol III, Baku, 2006.- $671 \mathrm{p}$.

20. Explanatory Dictionary of the Azerbaijani Language: in 4 volumes, vol IV, Baku, 2006. -708 p.

21. Gemalmaz E. Erzurum Region Dialects, vol I. Ankara, 1995. - 410 p.

22. Gurbanov A. Modern Azerbaijani Literary Language, vol I. Baku, 2003. - 450 p.

23. Hajiyev T. I. The History of Azerbaijani Literary Language, vol I. Baku, 2012. - 475 p.

24. Iraq-Turkmen Dialect, Baku, 2004. - 422 p.

25. Jafaroglu A. Compilation of Anatolia Regions' Dialects (Dialects of Van, Bitlis, Mush, Karakose, Eskisehir, Bolu and Zonguldak regions). Ankara, 1995. - 288 p.

26. Jafaroglu A. Compilation of East Regions' Dialects (Kars, Erzurum, Coruh Provinces' dialects). Ankara, 1995. - 296 p.

27. Karahan L. Classification of Anatolia Dialects. Ankara, 2011. - 203 p.

28. Kara M. Turkmen Grammar. Ankara, 2005. - 231 p.

29. Korkmaz Z. South-West Anatolia Dialects, Phonetics. Ankara, 1994. - 130 p.

30. Mammadli M. Azerbaijan Dialectology. Baku, 2019. - 352 p.

31. Sevortyan E. V. Etymological Dictionary of Turkic languages (general Turkic and inter-Turkic based on the letters "B", "G" and "D"). Moscow, 1980.

32. Shiraliyev M. Fundamentals of Azerbaijan dialectology. Baku, 2008. - 415 p. 